Herzschr Elektrophys 2018 $29: 62-69$ https://doi.org/10.1007/s00399-018-0553-3 Received: 12 December 2017

Accepted: 22 December 2017

Published online: 1 February 2018

(c) Springer Medizin Verlag GmbH, ein Teil von Springer Nature 2018

CrossMark

\author{
Alexander Klesen ${ }^{1,2} \cdot$ Dorothee Jakob ${ }^{1,2} \cdot$ Ramona Emig $^{1,2} \cdot$ Peter Kohl ${ }^{1,2} \cdot$ \\ Ursula Ravens $^{1,2} \cdot$ Rémi Peyronnet $^{1,2}$ \\ 'Institute for Experimental Cardiovascular Medicine, University Heart Center, Medical Center-University \\ of Freiburg, Freiburg i. Br., Germany \\ ${ }^{2}$ Faculty of Medicine, University of Freiburg, Freiburg, Germany
}

\title{
Cardiac fibroblasts
}

\section{Active players in (atrial) electrophysiology?}

Cardiomyocytes account for about one third of all cells in the heart, and until recently, fibroblasts were considered the most abundant nonmyocyte cell population in the myocardium [1]. Nonmyocytes such as endothelial cells, fibroblasts, and macrophages form the majority of cardiac cells, and while the exact proportions of individual nonmuscle cells are still a matter of debate [2], their roles in cardiac structural and functional integration have become one of the hottest cardiac research topics (see reviews [3, 4]). After a brief summary of general functions of fibroblasts, the current review will focus on new insights into the direct and indirect effects of fibroblasts on cardiac electrophysiology with special reference to atrial fibrillation (AF).

\section{Functions of cardiac fibroblasts}

Cardiac fibroblasts are highly heterogeneous mesenchymal cells of diverse origin: During heart development, myocardial fibroblasts develop from epithelial cells of the proepicardium by "epithelial-mesenchymal transition," whereas valvular fibroblasts derive from the endocardium via "endothelial-mesenchymal transition." In addition, fibroblasts may be generated from perivascular cells, endothelium, monocytes, bone marrowderived progenitor cells and fibrocytes [5].

In the past few decades, the unquestioned role of fibroblasts in the structural integrity of the heart has been

A. Klesen and D. Jakob contributed equally to this work. supplemented by multiple detailed functions of these cells, including production and degradation of extracellular matrix (ECM) proteins such as collagens and proteoglycans by a fine balance of metalloproteinases (MMP) and tissue inhibitors of MMP. Fibroblasts secrete inflammatory cytokines and humoral mediators. Upon activation, they differentiate into myofibroblasts. In addition, they may modulate cardiac electrophysiology (for reviews, see [6, 7]). Excessive fibroblast activation can cause fibrosis, which is defined as the accumulation of ECM, especially type I collagen [8].

\section{Distinction between fibroblasts and myofibroblasts}

Unlike the stellate appearance of fibroblasts in other organs, cardiac fibroblasts are mostly sheet- or spindle-shaped. Their morphology in culture is highly variable ( $\mathbf{F i g . 1 a}$ ) and hard to distinguish from other cultured cells, such as bone marrow-derived progenitor cells or fibroblasts from skin ( Fig. 1b-d). Fibroblasts stain positive for a number of proteins (hFSP [human fibroblast surface protein], DDR-2 [discoidin domain receptor 2], CD-90 [cluster of differentiation 90], Sca-1 [stem cells antigen1], intermediate filament vimentin), but none of these markers are unique to fibroblasts, and their expression may vary according to the tissue origin [9]. However, more recently identified markers such as tcf21(transcription factor 21) and periostin show great promise [3].

Upon mechanical or chemical stimulation, fibroblasts become activated, i.e., they proliferate, migrate, produce ECM
$[10,11]$, and differentiate into cells that express contractile filaments consisting of $a$-smooth muscle actin ( $\alpha$-SMA). Because of their ability to actively deform, they are called "myofibroblasts" [12]. In the heart, they can be characterized by positive staining for vimentin and $\alpha$-SMA (e. g., [13]), although a subset of smooth muscle cells may also express vimentin in addition to $\alpha$-SMA [5]. Myofibroblasts also exhibit high heterogeneity in phenotype [14].

Myofibroblasts play a pivotal role in wound healing and tissue remodeling after myocardial injury because they can replace damaged cells with fibrillar collagen, strengthening remodeled tissue $[15,16]$. Interestingly, differentiation of fibroblasts into myofibroblasts also seems to play a role in the pathophysiology of AF [17]. There is evidence from tachy-paced cardiomyocytes that high rates of electrical activation induce cardiomyocytes to secret factors into the culture medium that transmit activation of fibroblasts [18].

In clinical terms, $\mathrm{AF}$ is associated with interstitial fibrosis $[19,20]$, which in turn correlates with structural remodeling and plays a role in sustenance of the arrhythmia [17]. Although fibroblasts and myofibroblasts are not electrically excitable, they may affect the electrophysiological properties of cardiomyocytes either indirectly or directly. These issues will be discussed in the following sections. 


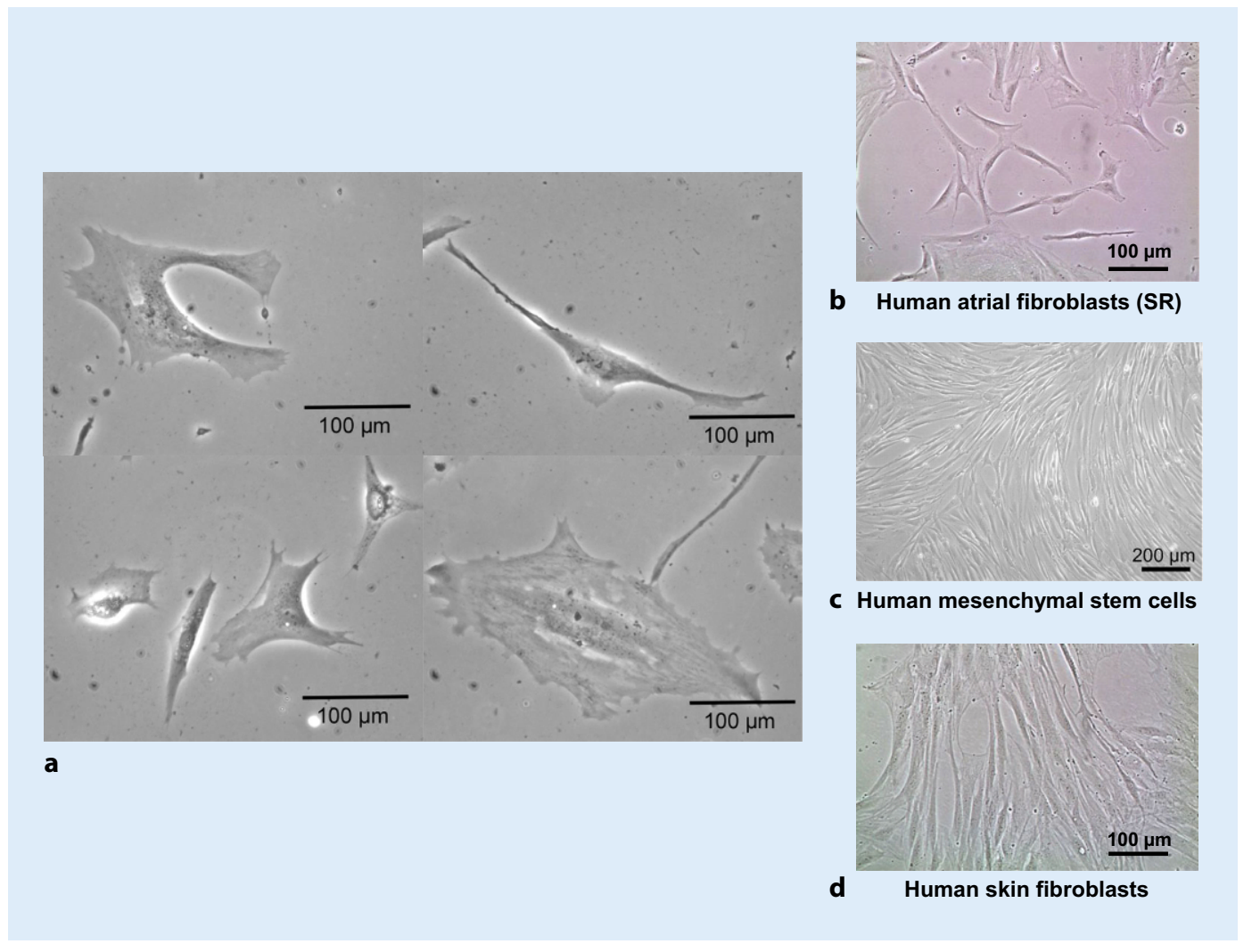

Fig. $1<$ Light microscopy images of human atrial fibroblasts from a patient in sinus rhythm at high magnification and low density to illustrate the heterogeneity in cellular shapes (a); images at lower magnification of human atrial fibroblasts (b), human bone marrow-derived mesenchymal stem cells (c), and human skin fibroblasts (d). (c Reproduced from [60] with permission of the publisher, $\mathbf{a}, \mathbf{b}, \mathbf{d}$ unpublished data)

\section{Indirect effects of fibroblasts on cardiac electrophysiological properties}

Electrical excitation spreads between cardiomyocytes due to direct coupling of neighboring cells via gap junctions consisting of connexins. These are mainly located at the short ends of cardiomyocytes. Therefore, the conduction velocity in healthy myocardium is higher in the locally prevailing cell direction than perpendicular to the cell orientation. The longitudinal direction is also favored owing to insulation of myocyte layers by ECM.

Heart disease is often associated with increased collagen deposition (fibrosis). Distinct although often mixed distribution patterns of collagen in the myocardium allow one to define different types of fibrosis, i. e., interstitial, compact, diffuse, or patchy fibrosis [21], with characteristic effects on impulse propagation. In human dilated cardiomyopathy requiring heart transplantation, for example, the percentage of collagen in a selected area of the left ventricle correlated with the heterogene- ity of conduction. Patients with mildto-moderate disturbances of activation patterns showed increasing degrees of interstitial fibrosis, whereas patients with severe conductance disturbances exhibited replacement fibrosis and microscars [22]. Interestingly, induction of heart failure by ventricular tachy-pacing in dogs caused interstitial fibrosis also in the atria, facilitating the induction of AF due to the formation of discrete atrial regions with slow conduction [23]. Recently, an expert consensus report suggested that human atrial pathologies can be divided into four classes of "atrial cardiomyopathies", two of which are dependent on fibroblasts or cardiomyocyte-fibroblast interactions [24].

\section{Direct coupling of cardiomyo- cytes and fibroblasts}

So far, we have discussed indirect interactions between fibroblasts and cardiomyocytes due to ECM, but there is also compelling evidence that the two cell types can directly couple to each other via connexin-based gap junctions (for a recent review, see [25]).
In fact, electrical coupling between fibroblasts/myofibroblasts and ventricular cardiomyocytes has been demonstrated not only in co-culture conditions [26-28], but also in the whole heart [29]. Heterotypic cell connections were also demonstrated in atria $[30,31]$ and atrioventricular nodes [32], where the first proof of an electrophysiological effect of nonmyocytes (in this case, resident macrophages) on cardiac electrical conduction was directly confirmed in native tissue [33].

The schematic drawings in - Fig. 2 illustrate the consequences of heterocellular coupling via gap junctions for membrane potential and impulse propagation. Electrical coupling of two cardiomyocytes with similar resting potentials will be without consequence for either cell in resting conditions (- Fig. 2a). Since the resting potential in fibroblasts is less negative than in cardiomyocytes, heterocellular coupling will influence the membrane potentials of the two cell types in opposite directions, i.e., the membrane potential of the fibroblast becomes more negative whereas that of the cardiomyocyte will 
be slightly less negative (• Fig. 2b). In addition, effects of heterocellular electrotonic coupling are thought to be dependent on the cardiac contractile cycle [34]. With respect to the electrical cycle, an action potential in the first cardiomyocyte will induce an electrotonically mediated potential change in the fibroblast. This, in turn, may cause sufficient depolarization of the next cardiomyocyte to reach the threshold potential, leading to passive propagation of an action potential through a nonexcitable cell, although with some delay (- Fig. 2c). The respective experimental recordings of membrane potentials in cardiomyocytes and fibroblasts have been documented [26]. However, if more than one fibroblast is interposed between the cardiomyocytes, the depolarization of the distant cardiomyocyte may not be sufficiently large to reach threshold and impulse propagation will fail (- Fig. 2d). In cell culture experiments with neonatal rat cells, conduction fails if the bridging distance is larger than $\sim 300 \mu \mathrm{m}$ [27]. Several groups are working with computer simulations of these results in order to understand better the complex electrical interactions between cardiomyocytes and fibroblasts [35-38].

Cardiomyocyte-fibroblast interactions become clinically relevant in the context of catheter ablation, which is currently the most effective way to stop or attenuate re-entries underlying AF. The scars generated in response to these interventions are essentially made of ECM proteins and fibroblasts leading to a nonconductive barrier. To overcome sustained AF, it is crucial that these regions are and remain nonconductive. Nevertheless, the high rate of reoccurrence of AF after catheter ablation [39, 40] suggests that scars may fail to block re-entries. This is at least in part caused by the resumption of electrical conductance due to heterocellular coupling in the scar tissue. Another clinically relevant aspect of cardiomyocyte-fibroblast interactions is the formation of scar tissue in response to myocardial infarction. Fibroblasts may electrically bridge gaps between surviving cardiomyocytes, thereby increasing the conductivity of the lesions and improving cardiac func-

Herzschr Elektrophys 2018 $29: 62-69$ https://doi.org/10.1007/s00399-018-0553-3

(c) Springer Medizin Verlag GmbH, ein Teil von Springer Nature 2018

A. Klesen · D. Jakob · R. Emig · P. Kohl · U. Ravens · R. Peyronnet

Cardiac fibroblasts. Active players in (atrial) electrophysiology?

\section{Abstract}

Fibrotic areas in cardiac muscle-be it in ventricular or atrial tissue-are considered as obstacles for conduction of the excitatory wave and can therefore facilitate re-entry, which may contribute to the sustenance of cardiac arrhythmias. Persistence of one of the most frequent arrhythmias, atrial fibrillation (AF), is accompanied by enhanced atrial fibrosis. Any kind of myocardial perturbation, whether via mechanical stress or ischemic damage, inflammation, or irregular and highfrequency electrical activity, activates fibroblasts. This leads to the secretion of paracrine factors and extracellular matrix proteins, especially collagen, and to the differentiation of fibroblasts into myofibroblasts. Excessive collagen production is the hallmark of fibrosis and impairs regular impulse propagation. In addition, direct electrical coupling between cardiomyocytes and nonmyocytes, such as fibroblasts and macrophages, via gap junctions affects conduction. Although fibroblasts are not electrically excitable, they express functional ion channels, in particular $\mathrm{K}^{+}$channels and mechanosensitive channels, some of which could be involved in tissue remodeling. Here, we briefly review these aspects with special reference to $A F$.

\section{Keywords}

Atrial Fibroblasts - Myofibroblasts · Cardiomyocytes - Electrophysiological phenomena . Atrial fibrillation

\section{Kardiale Fibroblasten. Aktive Mitspieler in der (atrialen) Elektrophysiologie?}

\section{Zusammenfassung}

Fibrotische Myokardbereiche - in den Herzkammern wie auch in den Vorhöfen stellen ein Hindernis für die Erregungsausbreitung dar, sie können deshalb kreisende Erregungen („re-entry“) fördern und so zum Aufrechterhalten von Herzrhythmusstörungen beitragen. Die Chronifizierung einer der häufigsten Arrhythmien, des Vorhofflimmerns, ist assoziiert mit atrialer Fibrose. Jede Art von kardialer Schädigung - etwa durch Ischämie, Entzündung oder hochfrequente, irreguläre elektrische und mechanische Aktivierung wie z. B. beim Vorhofflimmern - transformiert Fibroblasten in ihre aktivierte Form. Dies führt zur Sekretion parakriner Faktoren und extrazellulärer Matrixproteine, insbesondere Kollagen, und zur Differenzierung von Fibroblasten in Myofibroblasten. Das Hauptmerkmal der Fibrose ist eine gesteigerte Kollagenproduktion, die die reguläre Erregungsausbreitung beeinträchtigt. Nichtmuskelzellen, wie Fibroblasten oder Makrophagen, können außerdem durch direkte Kontakte zu Kardiomyozyten über "gap junctions" einen modulierenden Einfluss auf die Erregungsleitung nehmen. Obwohl sie selbst nicht elektrisch aktiv sind, exprimieren Fibroblasten eine Reihe von lonenkanälen, insbesondere $\mathrm{K}^{+}$-Kanäle und mechanosensitive Kanäle, von denen einige möglicherweise am strukturellen Umbau des Myokards beteiligt sind. In dem vorliegenden kurzen Übersichtsartikel werden diese Aspekte im Zusammenhang mit Vorhofflimmern diskutiert.

\section{Schlüsselwörter}

Atriale Fibroblasten - Myofibroblasten . Kardiomyozyten · Elektrophysiologische Eigenschaften · Vorhofflimmern tion. These examples highlight the importance of better understanding fibroblast-fibroblast and fibroblast-cardiomyocyte coupling to be able to make better scars: either nonconducting or electrically transparent; scars may be a desirable target, depending on clinical context.

\section{Electrophysiological properties of fibroblasts}

Cardiac fibroblasts are not electrically excitable. Nevertheless, they express a plethora of ion channels, mainly potassium $\left(\mathrm{K}^{+}\right)$channels and mechanosensitive channels, that contribute to their resting membrane potential [41, 42]. Typical membrane potential values re- 


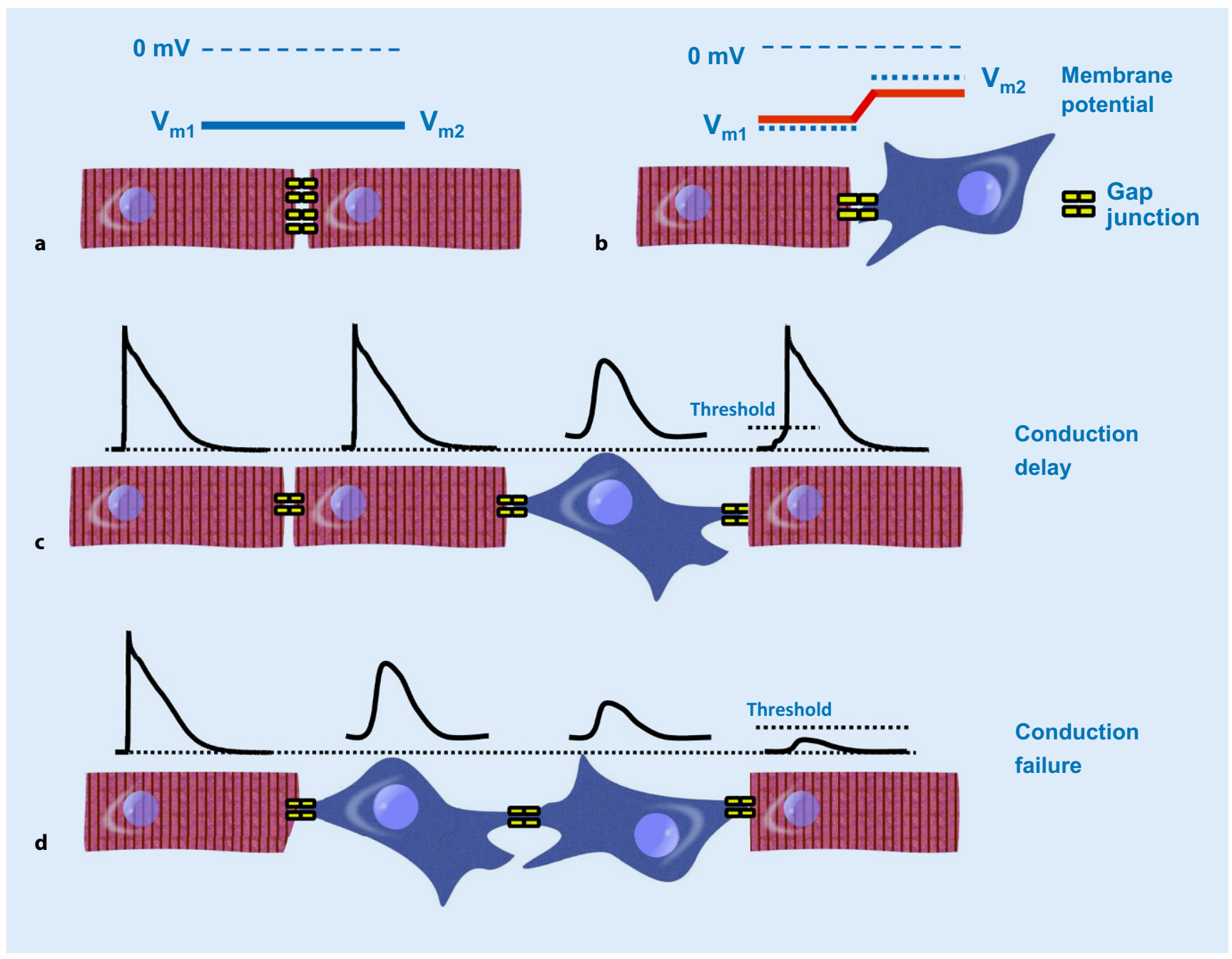

Fig. 2 Schematic drawing of the influence of cardiomyocyte-fibroblast coupling on membrane potentials and impulse propagation. a Coupling between two cardiomyocytes of similar resting potential (i. e., human atrial cardiomyocytes, $-74.0 \pm 0.9 \mathrm{mV}, n=238$ cells from 221 patients in sinus rhythm; [61]): no change. b Coupling of cardiomyocyte to fibroblast (resting potential of human atrial fibroblasts, $-35.1 \pm 4.2 \mathrm{mV}, n=31$ from seven patients in sinus rhythm; [13]): depolarization of cardiomyocyte, hyperpolarization of fibroblast. c Intercalation of a single coupled fibroblast: conduction delay (see also [26]). d Intercalation of several coupled fibroblasts: failure of conduction (e. g., when bridging distances of $>300 \mu \mathrm{m}$ in culture, [27])

ported for cultured human atrial fibroblasts/myofibroblasts are $\sim-35 \mathrm{mV}$ [13]. It must be emphasized, however, that data on fibroblast membrane potential and ion channels in the literature show substantial variability depending on the experimental conditions and material (different species, ventricular versus atrial fibroblasts, freshly isolated versus cultured cells). Thus, in vitro [43] and in situ [25] recordings in rat suggest the presence of even less negative resting potentials (up to $-20 \mathrm{mV}$ ).

In rat ventricular fibroblasts, the resting membrane potential is determined by an inwardly rectifying $\mathrm{K}^{+}$current [41]. Li etal. [44] published a relative distribution of ion channel expression and respective currents in cultured adult human ventricular fibroblasts. In this study, $88 \%$ of fibroblasts exhibited current flow via $\mathrm{Ca}^{2+}$ activated $\mathrm{K}^{+}$channels of large conductance $\left(\mathrm{BK}_{\mathrm{Ca}}\right) ; 15 \%$ had a delayed rectifier current $\left(\mathrm{IK}_{\mathrm{DR}}\right), 14 \%$ a transient outward current $\left(\mathrm{I}_{\mathrm{to}_{\mathrm{o}}}\right), 24 \%$ an inward rectifying $\mathrm{K}^{+}$ current $\left(\mathrm{IK}_{\mathrm{ir}}\right), 7 \%$ a chloride current $\left(\mathrm{I}_{\mathrm{Cl}}\right)$, and $61 \%$ a Na ${ }^{+}$current $\left(\mathrm{I}_{\mathrm{Na}}\right)$. The respective cardiac ion channels responsible for these currents were also expressed [44]. In mouse ventricular fibroblasts, $\mathrm{I}_{\mathrm{K}, \mathrm{ATP}}$ was detected [45], but no reports for human fibroblasts are available. Similarly, human atrial fibroblasts also showed inward and outward rectifying and transient outward currents ( $\bullet$ Fig. 3a, b, and [13]), although the percentage of cells exhibiting these currents was not reported [13]. These authors did not detect any effect of the $\mathrm{BK}_{\mathrm{Ca}}$ channel blocker paxilline $(1 \mu \mathrm{M})$, whereas $\mathrm{BK}_{\mathrm{Ca}}$ channel activity was clearly present in a line of ventricular fibroblasts obtained from healthy human hearts [46]. Moreover, $\mathrm{BK}_{\mathrm{Ca}}$ channels are claimed to contribute to cardiomyocytes-fibroblast coupling [46].

Chatelier et al. [47] reported that freshly isolated human atrial fibroblasts neither express $\alpha$-SMA nor exhibit 


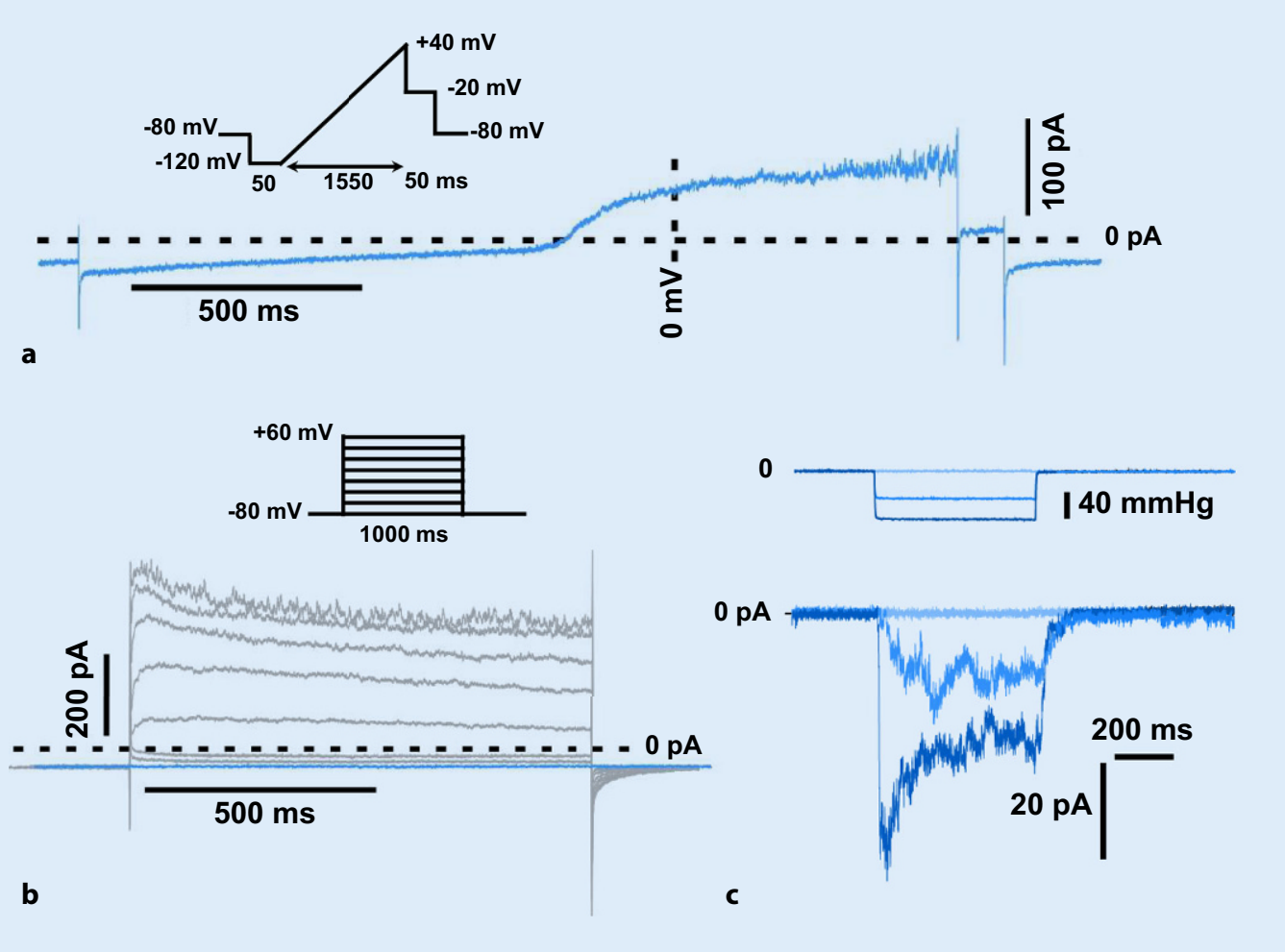

Fig. $3<$ Examples of currents in response to different experimental protocols in fibroblasts cultured from human right atrial appendages of patients in sinus rhythm. a Current flow during a ramp step from -120 to $+40 \mathrm{mV}$ (see inset); $\mathbf{b}$ currents in response to clamp steps to various voltages (inset); c current in response to negative pressure applied to the cell patch under the pipette (a-c unpublished data)

any sodium $\left(\mathrm{Na}^{+}\right)$currents. However, between day 7 and day 12 of culture, atrial fibroblasts start to differentiate into a-SMA-expressing myofibroblasts. In addition, after day $12, \mathrm{Na}^{+}$current and expression of the $\mathrm{Na}^{+}$channel $\alpha$-subunit Nav1.5 were detected in all cells. We have previously reported larger $\mathrm{Na}^{+}$currents in fibroblasts cultured from patients in AF compared with sinus rhythm. These currents were not affected by $100 \mathrm{nM}$ tetrodotoxin, but required the high concentration of $10 \mu \mathrm{M}$ tetrodotoxin for $90 \%$ block, suggesting that they represent cardiac Nav1.5 channels [13].

In freshly dissociated adult rat ventricular fibroblasts, mechanosensitive channels, i.e., a cation nonselective, gadolinium-sensitive channel that was enhanced by compression and inhibited by stretch, have been described [42]. In our own preliminary experiments with human atrial fibroblasts from patients in sinus rhythm or AF, we too detected stretch-activated channels by applying negative pressure to cell-attached patches (- Fig. 3c). On the other hand, shear stress induced large outward currents in rat atrial myocytes by enhancing insertion of Kv 1.5 channels [48].
Involvement of fibroblast
ion channels in non-
electrophysiological effects

Functionally significant ion fluxes in nonexcitable cells were noticed decades ago. However, the role of ion channels in non-electrophysiological events, such as immunological responses or proliferation and migration of cancer cells, was appreciated only in the 1980s, when patch clamp techniques became generally available (for a review, see [49]). Interestingly, mechanosensitive channels are also involved in many forms of cancer (see review in this issue [50]). Besides controlling membrane potential, ion channels in concert with pumps and transporters regulate cellular calcium homeostasis, thereby affecting cell metabolism via this ubiquitous intracellular transmitter. The link between ion channels, intracellular calcium levels, and control of proliferation and migration has led to the strategy of targeting various ion channels for cancer therapy [51-53]. Moreover, voltage-gated $\mathrm{Na}^{+}$channels are upregulated by positive feedback in many types of cancer and are thought to facilitate metastatic processes [54].

The findings in cancer research have stimulated investigations into the role of ion channels in proliferation and migration of fibroblasts in search for putative therapeutic strategies against fibrosis. For instance, selective block of $\mathrm{K}_{\mathrm{Ca}} 3.1$ channels $\left(\mathrm{Ca}^{2+}\right.$ activated $\mathrm{K}^{+}$channel of intermediate conductance) with TRAM-34 (1((2-chlorophenyl)diphenylmethyl)-1Hpyrazole) attenuated human lung myofibroblast proliferation and was hence suggested to have therapeutic potential in idiopathic pulmonary fibrosis [55]. Interestingly, ether-á-go-go $\mathrm{K}^{+}$channels regulate fibroblast proliferation independent of ion fluxes, as demonstrated with nonconducting channel mutants that act merely by channel conformation changes [56].

With respect to cardiac fibroblasts, members of the transient receptor potential (TRP) channel family have been reported to regulate $\mathrm{Ca}^{2+}$ influx and downstream signaling. For instance, TRPM7 $\left(\mathrm{Ca}^{2+}\right.$-permeable melastatin type-7 TRP) channels were shown to promote fibroblast-myofibroblast transition 
fostering remodeling in AF [57]. TRPC3 ( $\mathrm{Ca}^{2+}$-permeable canonical type-3 TRP) channels are upregulated in AF and have also been associated with atrial remodeling via $\mathrm{Ca}^{2+}$-activated proliferation and differentiation of fibroblasts [58]. High concentrations of tetrodotoxin, a selective blocker of $\mathrm{Na}^{+}$channels, do not impair proliferation of cultured human atrial fibroblasts neither from patients in AF nor those in sinus rhythm [13], and similar results were also found for human ventricular fibroblasts [59]. In addition, proliferation of ventricular cells is also suppressed when $\mathrm{BK}_{\mathrm{Ca}}$ is blocked by paxilline, or when the volume-sensitive chloride current is blocked by DIDS $\left(4,4^{\prime}\right.$-diisothiocyanatostilbene$2,2^{\prime}$-disulfonic acid disodium). Furthermore, knock-down of the respective ion channel genes KCa1.1 or ClCN3 (chloride voltage-gated channel 3) markedly reduces cell growth [59], indicating that these ion channels contribute to the regulation of proliferation, possibly by modulating membrane potential and cell volume [59]. Therefore, targeted block of fibroblast ion channels could have therapeutic potential for prevention or amelioration of fibrosis in heart and lung tissues.

\section{Conclusion}

Many open questions remain to be an-
swered regarding the role of fibroblasts
and myofibroblasts in atrial pathophys-
iology. New techniques that allow for
the reliable identification of the func-
tional state of an individual cell are
needed in order to elucidate putative
associations between ion channels
and function in more detail. The inher-
ent heterogeneity of cell populations
should be characterized by measur-
ing single cell expression patterns of
ion channels and other functional pro-
teins. These efforts are a prerequisite
for defining promising targets that may
refine interventions aiming at efficient
disease prevention and control.

Many open questions remain to be answered regarding the role of fibroblasts pathophysthe reliable identification of the func tional state of an individual cell are needed in order to elucidate putative associations between ion channels and function in more detail. The inherent heterogeneity of cell populations should be characterized by measuring single cell expression patterns of ion channels and other functional proteins. These efforts are a prerequisite for defining promising targets that may disease prevention and control.

\section{Corresponding address}

\section{Dr. R. Peyronnet}

Institute for Experimental Cardiovascular Medicine, University Heart Center, Medica Center-University of Freiburg

Elsässer Str. 2q, 79110 Freiburg i. Br., Germany remi.peyronnet@universitaets-herzzentrum.de

\section{Compliance with ethical guidelines}

Conflict of interest. A. Klesen, D. Jakob, R. Emig, P. Kohl, U. Ravens, and R. Peyronnet declare that they have no competing interests.

All human samples collected for research are by the CardioVascular BioBank of the University Heart Centre Freiburg-Bad Krozingen, which received ethical approval covering the required tissue collection and proposed experimental characterization (Reference 393/16, approval by the Ethics Commission of the Albert Ludwigs University of Freiburg).

\section{References}

1. Souders CA, Bowers SL, Baudino TA (2009) Cardiac fibroblast: the renaissance cell. Circ Res 105:1164-1176. https://doi.org/10.1161/ circresaha.109.209809

2. Pinto AR, Ilinykh A, Ivey MJ, Kuwabara JT, D'Antoni ML, Debuque R, Chandran A, Wang L, Arora K, Rosenthal NA, Tallquist MD (2016) Revisiting cardiac cellular composition. Circ Res 118:400-409. https://doi.org/10.1161/circresaha. 115.307778

3. Tallquist MD, Molkentin JD (2017) Redefining the identity of cardiac fibroblasts. Nat Rev Cardiol 14:484-491. https://doi.org/10.1038/nrcardio. 2017.57

4. Gourdie RG, Dimmeler S, Kohl P (2016) Novel therapeutic strategies targeting fibroblasts and fibrosis in heart disease. Nat Rev Drug Discov 15:620-638. https://doi.org/10.1038/nrd.2016.89

5. Krenning G, Zeisberg EM, Kalluri R (2010) The origin of fibroblasts and mechanism of cardiac fibrosis. J Cell Physiol 225:631-637. https://doi.org/10. 1002/jcp.22322

6. Kohl P, Gourdie RG (2014) Fibroblast-myocyte electrotonic coupling: does it occur in native cardiac tissue? J Mol Cell Cardiol 70:37-46. https:// doi.org/10.1016/j.yjmcc.2013.12.024

7. Ongstad E, Kohl P (2016) Fibroblast-myocyte coupling in the heart: potential relevance for therapeutic interventions. J Mol Cell Cardiol 91:238-246. https://doi.org/10.1016/j.yjmcc. 2016.01.010

8. Manabel, ShindoT, Nagai R(2002) Gene expression in fibroblasts and fibrosis: involvement in cardiac hypertrophy. Circ Res 91:1103-1113. https://doi. org/10.1161/01.RES.0000046452.67724.B8

9. Powell DW, Mifflin RC, Valentich JD, Crowe SE, Saada Jl, West AB (1999) Myofibroblasts. I. Paracrine cells important in health and disease. Am J Physiol 277:C1-9. https://doi.org/10.1152/ ajpcell.1999.277.1.C1

10. Brown RD, Ambler SK, Mitchell MD, Long CS (2005) The cardiac fibroblast: therapeutic target in myocardial remodeling and failure. Annu Rev Pharmacol Toxicol 45:657-687. https://doi.org/10. 1146/annurev.pharmtox.45.120403.095802

11. Berk BC, Fujiwara K, Lehoux S (2007) ECM remodeling in hypertensive heart disease. J Clin Invest 117:568-575. https://doi.org/10.1172/ jci31044

12. Gabbiani G, Hirschel BJ, Ryan GB, Statkov PR, Majno $G$ (1972) Granulation tissue as a contractile organ. A study of structure and function. J Exp Med 135:719-734. https://doi.org/10.1084/jem.135.4. 719

13. Poulet C, Kunzel S, Buttner E, Lindner D, Westermann D, Ravens U (2016) Altered physiological functions and ion currents in atrial fibroblasts from patients with chronic atrial fibrillation. Physiol Rep. https://doi.org/10.14814/phy2.12681

14. Gabbiani G (1996) The cellular derivation and the life span of the myofibroblast. Pathol Res Pract 192:708-711. https://doi.org/10.1016/s03440338(96)80092-6

15. Cleutjens JP, Verluyten MJ, Smiths JF, Daemen MJ (1995) Collagen remodeling after myocardial infarction in the rat heart. Am JPathol 147:325-338

16. Hinz B, Phan SH, Thannickal VJ, Galli A, BochatonPiallat ML, Gabbiani G (2007) The myofibroblast: one function, multiple origins. Am J Pathol 170:1807-1816. https://doi.org/10.2353/ajpath. 2007.070112

17. Yue L, Xie J, Nattel S (2011) Molecular determinants of cardiac fibroblast electrical function and therapeutic implications for atrial fibrillation. Cardiovasc Res 89:744-753. https://doi.org/10. 1093/cvr/cvq329

18. Burstein B, Qi XY, Yeh YH, Calderone A, Nattel $S$ (2007) Atrial cardiomyocyte tachycardia alters cardiac fibroblast function: a novel consideration in atrial remodeling. Cardiovasc Res 76:442-452. https://doi.org/10.1016/j.cardiores.2007.07.013

19. Frustaci A, Chimenti C, Bellocci F, Morgante E, Russo MA, Maseri A (1997) Histological substrate of atrial biopsies in patients with lone atrial fibrillation. Circulation 96:1180-1184. https://doi.org/10. 1161/01.CIR.96.4.1180

20. Boldt A, Wetzel U, Lauschke J, Weigl J, Gummert J, Hindricks G, Kottkamp H, Dhein S (2004) Fibrosis in left atrial tissue of patients with atrial fibrillation with and without underlying mitral valve disease. Heart 90:400-405. https://doi.org/10.1136/hrt. 2003.015347

21. de Jong $S$, van Veen TA, van Rijen HV, de Bakker JM (2011) Fibrosis and cardiac arrhythmias. J Cardiovasc Pharmacol 57:630-638. https://doi. org/10.1097/FJC.0b013e318207a35f

22. Anderson KP, Walker R, Urie P, Ershler PR, Lux RL, Karwandee SV (1993) Myocardial electrical propagation in patients with idiopathic dilated cardiomyopathy. J Clin Invest 92:122-140. https:// doi.org/10.1172/jci116540

23. Li D, Fareh S, Leung TK, Nattel S (1999) Promotion of atrial fibrillation by heart failure in dogs: atrial remodeling of a different sort. Circulation 100:87-95

24. Mairesse GH, Moran P, Van Gelder IC, Elsner C, Rosenqvist M, Mant J, Banerjee A, Gorenek B, Brachmann J, Varma N, Glotz de Lima G, Kalman J, Claes N, Lobban T, Lane D, Lip GYH, Boriani $G$ (2017) Screening for atrial fibrillation: a European Heart Rhythm Association (EHRA) consensus document endorsed by the Heart Rhythm Society (HRS), Asia Pacific Heart Rhythm Society (APHRS), and Sociedad Latinoamericana de Estimulacion Cardiaca y Electrofisiologia 
(SOLAECE). Europace 19:1589-1623. https://doi. org/10.1093/europace/eux177

25. Pellman J, Zhang J, Sheikh F (2016) Myocytefibroblast communication in cardiac fibrosis and arrhythmias: mechanisms and model systems. J Mol Cell Cardiol 94:22-31. https://doi.org/10. 1016/j.yjmcc.2016.03.005

26. Kohl P, Kamkin AG, Kiseleva IS, Noble D (1994) Mechanosensitive fibroblasts in the sino-atrial node region of rat heart: interaction with cardiomyocytes and possible role. Exp Physiol 79:943-956. https://doi.org/10.1113/expphysiol. 1994.sp003819

27. Gaudesius G, Miragoli M, Thomas SP, Rohr S (2003) Coupling of cardiac electrical activity over extended distances by fibroblasts of cardiac origin. Circ Res 93:421-428. https://doi.org/10.1161/01. res.0000089258.40661.0C

28. Camelliti P, Green CR, Kohl P (2006) Structural and functional coupling of cardiac myocytes and fibroblasts. Adv Cardiol 42:132-149. https://doi. org/10.1159/000092566

29. Quinn TA, Camelliti P, Rog-Zielinska EA, Siedlecka U, Poggioli T, O'Toole ET, Knopfel T, Kohl P (2016) Electrotonic coupling of excitable and nonexcitable cells in the heart revealed by optogenetics. Proc Natl Acad Sci U S A 113:14852-14857. https://doi.org/10.1073/pnas. 1611184114

30. Kohl P, Camelliti P (2012) Fibroblast-myocyte connections in the heart. Heart Rhythm 9:461-464. https://doi.org/10.1016/j.hrthm.2011. 10.002

31. Camelliti P, Green CR, LeGrice I, Kohl P (2004) Fibroblast network in rabbit sinoatrial node: structural and functional identification of homogeneous and heterogeneous cell coupling. Circ Res 94:828-835. https://doi.org/10.1161/01.res. 0000122382.19400 .14

32. Nisbet AM, Camelliti P, Walker NL, Burton FL, Cobbe SM, Kohl P, Smith GL (2016) Prolongation of atrioventricular node conduction in a rabbit model of ischaemic cardiomyopathy: role of fibrosis and connexin remodelling. J Mol Cell Cardiol 94:54-64. https://doi.org/10.1016/j.yjmcc.2016.03.011

33. Hulsmans M, Clauss S, Xiao L, Aguirre AD, King KR, Hanley A, Hucker WJ, Wulfers EM, Seemann G, Courties G, Iwamoto Y, Sun Y, Savol AJ, Sager $H B$, Lavine KJ, Fishbein GA, Capen DE, Da Silva N, Miquerol L, Wakimoto $\mathrm{H}$, Seidman $\mathrm{CE}$, Seidman JG, Sadreyev RI, Naxerova K, Mitchell RN, Brown D, Libby P, Weissleder R, Swirski FK, Kohl P, Vinegoni C, Milan DJ, Ellinor PT, Nahrendorf M (2017) Macrophages facilitate electrical conduction in the heart. Cell 169:510-522.e20. https://doi.org/10. 1016/j.cell.2017.03.050

34. Kamkin A, Kiseleva I, Wagner KD, Lammerich A, Bohm J, Persson PB, Gunther J (1999) Mechanically induced potentials in fibroblasts from human right atrium. Exp Physiol 84:347-356. https://doi.org/ 10.1111/j.1469-445X.1999.01794.x

35. Sachse FB, Moreno AP, Abildskov JA (2008) Electrophysiological modeling of fibroblasts and their interaction with myocytes. Ann Biomed Eng 36:41-56. https://doi.org/10.1007/s10439-0079405-8

36. Maleckar MM, Greenstein JL, Giles WR, Trayanova NA (2009) Electrotonic coupling between human atrial myocytes and fibroblasts alters myocyte excitability and repolarization. Biophys J 97:2179-2190. https://doi.org/10.1016/j.bpj. 2009.07.054

37. Xie Y, Garfinkel A, Camelliti P, Kohl P, Weiss JN, Qu Z (2009) Effects of fibroblast-myocyte coupling on cardiac conduction and vulnerability to reentry: a computational study. Heart Rhythm 6:1641-1649. https://doi.org/10.1016/j.hrthm.2009.08.003

38. Wülfers EM, Kohl P, Seemann G (2016) Small myocyte enclaves may facilitate conduction of excitation through scar tissue: A one-dimensional simulation study. Biomed Tech 61:s209

39. Calkins H, Hindricks G, Cappato R, Kim YH, Saad EB, Aguinaga L, Akar JG, Badhwar V, Brugada J, Camm J, Chen PS, Chen SA, Chung MK, Nielsen JC, Curtis AB, Davies DW, Day JD, d'Avila A, de Groot N, Di Biase $L$, Duytschaever $M$, Edgerton JR, Ellenbogen KA, Ellinor PT, Ernst S, Fenelon G, Gerstenfeld EP, Haines $D E$, Haissaguerre $M$, Helm RH, Hylek $E$, Jackman WM, Jalife J, Kalman JM, Kautzner J, Kottkamp $\mathrm{H}$ Kuck KH, Kumagai K, Lee R, Lewalter T, Lindsay BD, Macle L, Mansour M, Marchlinski FE, Michaud GF, Nakagawa H, Natale A, Nattel S, Okumura K, Packer D, Pokushalov E, Reynolds MR, Sanders P, Scanavacca M, Schilling R, Tondo C, Tsao HM, Verma A, Wilber DJ, Yamane T (2017) 2017 HRS/ EHRA/ECAS/APHRS/SOLAECE expert consensus statement on catheter and surgical ablation of atrial fibrillation: Executive summary. J Arrhythm 33:369-409. https://doi.org/10.1016/j.joa.2017. 08.001

40. Sawhney N, Anousheh R, Chen WC, Narayan S, Feld GK (2009) Five-year outcomes after segmental pulmonary vein isolation for paroxysmal atrial fibrillation. Am J Cardiol 104:366-372. https://doi. org/10.1016/j.amjcard.2009.03.044

41. Chilton L, Ohya S, Freed D, George E, Drobic V, Shibukawa Y, Maccannell KA, Imaizumi Y, Clark RB Dixon IM, Giles WR (2005) K+ currents regulate the resting membrane potential, proliferation, and contractile responses in ventricular fibroblasts and myofibroblasts. Am J Physiol Heart Circ Physiol 288:H2931-H2939. https://doi.org/10. 1152/ajpheart.01220.2004

42. Kamkin A, Kiseleva I, Wagner KD, Bohm J, Theres H, Gunther J, Scholz H (2003) Characterization of stretch-activated ion currents in isolated atrial myocytes from human hearts. Pflugers Arch 446:339-346. https://doi.org/10.1007/s00424002-0948-0

43. Rook MB, van Ginneken $A C$, de Jonge $B$, el Aoumari A, Gros D, Jongsma HJ (1992) Differences in gap junction channels between cardiac myocytes, fibroblasts, and heterologous pairs. Am J Physio 263:C959-C977. https://doi.org/10.1152/ajpcell. 1992.263.5.C959

44. Li GR, Sun HY, Chen JB, Zhou Y, Tse HF, Lau CP (2009) Characterization of multiple ion channels in cultured human cardiac fibroblasts. PLOS ONE 4:e7307. https://doi.org/10.1371/journal.pone. 0007307

45. Benamer N, Moha Ou Maati $H$, Demolombe S, Cantereau A, Delwail A, Bois P, Bescond $J$, Faivre JF (2009) Molecular and functional characterization of a new potassium conductance in mouse ventricular fibroblasts. J Mol Cell Cardio 46:508-517. https://doi.org/10.1016/j.yjmcc. 2008.12.016

46. Wang YJ, Sung RJ, Lin MW, Wu SN (2006) Contribution of $\mathrm{BK}(\mathrm{Ca})$-channel activity in human cardiac fibroblasts to electrical coupling of cardiomyocytes-fibroblasts. J Membr Biol 213:175-185. https://doi.org/10.1007/s00232007-0027-8

47. Chatelier A, Mercier A, Tremblier B, Theriault $O$, Moubarak M, Benamer N, Corbi P, Bois P, Chahine $M$, Faivre JF (2012) A distinct de novo expression of Nav1.5 sodium channels in human atrial fibroblasts differentiated into myofibroblasts.
JPhysiol 590:4307-4319. https://doi.org/10.1113/ jphysiol.2012.233593

48. Boycott HE, BarbierCS, Eichel CA, Costa KD, Martins RP, Louault F, Dilanian G, Coulombe A, Hatem SN, Balse $E$ (2013) Shear stress triggers insertion of voltage-gated potassium channels from intracellular compartments in atrial myocytes. Proc Natl Acad Sci USA 110:E3955-E3964. https:// doi.org/10.1073/pnas.1309896110

49. Chandy KG, Wulff $H$, Beeton $C$, Pennington $M$, Gutman GA, Cahalan MD (2004) K+ channels as targets for specific immunomodulation. Trends Pharmacol Sci 25:280-289. https://doi.org/10. 1016/j.tips.2004.03.010

50. Schmidt C, Peyronnet R (2018) Voltage-gated and stretch-activated potassium channels in the human heart: pathophysiological and clinical significance. Herzschrittmacherther Elektrophysiol. https://doi.org/10.1007/s00399017-0541-z

51. Conti M (2007) Targeting ion channels for new strategies in cancer diagnosis and therapy. Curr Clin Pharmacol 2:135-144. https://doi.org/10. 2174/157488407780598153

52. Arcangeli A, Crociani O, Lastraioli E, Masi A, Pillozzi S, Becchetti A (2009) Targeting ion channels in cancer: a novel frontier in antineoplastic therapy. Curr Med Chem 16:66-93. https://doi.org/10. 2174/092986709787002835

53. Becchetti A, Munaron L, Arcangeli A (2013) The role of ion channels and transporters in cell proliferation and cancer. Front Physiol 4:312. https://doi.org/10.3389/fphys.2013.00312

54. Fraser SP, Ozerlat-Gunduz I, Brackenbury WJ, Fitzgerald EM, Campbell TM, Coombes RC, Djamgoz MB (2014) Regulation of voltage-gated sodium channel expression in cancer: hormones, growth factors and auto-regulation. Philos Trans R Soc Lond, B, Biol Sci 369:20130105. https://doi. org/10.1098/rstb.2013.0105

55. Roach KM, Duffy SM, Coward W, Feghali-Bostwick C, Wulff $H$, Bradding P (2013) The K+ channel KCa3.1 as a novel target for idiopathic pulmonary fibrosis. PLoS ONE 8:e85244. https://doi.org/10. 1371/journal.pone.0085244

56. Hegle AP, Marble DD, Wilson GF (2006) A voltagedriven switch for ion-independent signaling by ether-a-go-go K+ channels. Proc Natl Acad Sci U SA 103:2886-2891. https://doi.org/10.1073/pnas. 0505909103

57. Du J, Xie J, Zhang Z, Tsujikawa H, Fusco D, Silverman D, Liang B, Yue L (2010) TRPM7-mediated Ca2+ signals confer fibrogenesis in human atrial fibrillation. Circ Res 106:992-1003. https://doi. org/10.1161/circresaha.109.206771

58. Harada M, Luo X, Qi XY, Tadevosyan A, Maguy A, Ordog B, Ledoux J, Kato T, Naud P, Voigt N, Shi Y, Kamiya K, Murohara T, Kodama I, Tardif JC, Schotten U, Van Wagoner DR, Dobrev D, Nattel $S$ (2012) Transient receptor potential canonical-3 channel-dependent fibroblast regulation in atrial fibrillation. Circulation 126:2051-2064. https:// doi.org/10.1161/circulationaha.112.121830

59. He ML, Liu WJ, Sun HY, Wu W, Liu J, Tse HF, Lau CP, Li GR (2011) Effects of ion channels on proliferation in cultured human cardiac fibroblasts. J Mol Cell Cardiol 51:198-206. https://doi.org/10.1016/j. yjmcc.2011.05.008

60. Heubach JF, GrafEM, Leutheuser J, Bock M, Balana B, Zahanich I, Christ T, Boxberger S, Wettwer E, Ravens U (2004) Electrophysiological properties of human mesenchymal stem cells. J Physiol 554:659-672. https://doi.org/10.1113/jphysiol. 2003.055806 
61. Ravens U, Katircioglu-Ozturk D, Wettwer E, Christ T, Dobrev D, Voigt N, Poulet C, Loose S, Simon J, Stein A, Matschke K, Knaut M, Oto E, Oto A, Guvenir HA (2015) Application of the RIMARC algorithm to a large data set of action potentials and clinical parameters for risk prediction of atrial fibrillation. Med Biol Eng Comput 53:263-273. https://doi. org/10.1007/s11517-014-1232-0 